\title{
Language and the African Philosophical Traditions
}

\author{
Kọlá Abímbọlá \\ Department of Philosophy \\ Howard University \\ Washington, DC \\ kolapo.abimbola@Howard.edu
}

\begin{abstract}
Are there universal principles, categories, or forms of reasoning that apply to all aspects of human experience-irrespective of culture and epoch? $\mathrm{Nu}$ merous scholars have explored this very question from Africana perspectives: Kwasi Wiredu (1996) explored the philosophical issue of whether there are culturally defined values and concepts; Hallen and Sodipo (1986) examined the question of whether there are unique African indigenous systems of knowledge; Ngũgĩ wa Thiong'o (1994) evaluated the role of colonialism in the language of African literature; Oyèrónkẹ Oyěwumi (1997) argued that "gender" is a Western cultural invention that is foreign to Yoru ba systems of sociation; and Helen Veran (2001) argued that even though science, mathematics, and logic are not culturally relative, "certainty" is nonetheless derived from cultural practices and associations. Building on these and other works, this essay argues that: (i) incommensurability of "worldviews," "perspectives," "paradigms," or "conceptual schemes" springs from deeper, more fundamental cognitive categories of logic that are coded into natural languages; and that (ii) consequently, as long as African reflective reasoning is expressed solely (or predominantly) in European languages, the authenticity of the "African" in African philosophy is questionable.
\end{abstract}

\section{Introduction: Logic and African Philosophy}

I propose to consider the African philosophical traditions via an examination of the soundness of Syllogism A. The use of abductive generalization as a method of proof will be crucial to demonstrating the truth of premise 1. 


\section{Syllogism A}

All philosophy is cultural

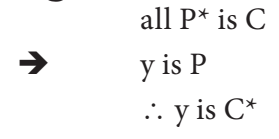

philosophy

Yoruba' thought is philosophy

$\therefore \mathrm{y}$ is $\mathrm{C}^{*}$

$\therefore$ Yoru bá thought is cultural

philosophy

I will proceed in this manner:

Following Harry J. Gensler's well-formed formulas (wffs) and his rules for syllogistic logic, I will very quickly show that Syllogism A is valid; then,

Devote the body of this article to establishing the soundness of Syllogism A; and then,

Conclude by drawing out the implication of premise 1 as follows: any type of African thought that is "philosophy" must also of necessity be "cultural philosophy."

I will then further draw the disturbing and paradoxical grand conclusion that the growth of philosophy in Africa is leading to the demise of African philosophy! For as long as we continue to conduct philosophy in Africa solely (or mainly) in European languages, the concepts, categories, and worldviews embedded within our philosophical products will predominantly be European and not African.

\section{Proof and Culture}

I define the terms well-formed formula, distribution, validity, the-truth-insoundness, culture, and deductive generalization as follows:

Well-formed formula: A well-formed formula $(w f f)$ is a sentence in syllogistic language having any of these eight forms:

$\begin{array}{llll}\text { all } \underline{A} \text { is } B & \text { some } A \text { is } B & x \text { is } A & x \text { is } y \\ \text { no } \underline{A} \text { is } \underline{B} & \text { some } A \text { is not } \underline{B} & x \text { is not } \underline{A} & x \text { is not } \underline{y}\end{array}$

Distribution: Each instance of a letter in a $w f f$ is distributed if and only if it occurs just after "all" or anywhere after "no" or "not." Hence, only the underlined letters in the $w f f s$ above are distributed.

Validity: A syllogism is valid if and only if it passes Gensler's two-step "star test":

i. "Star premise letters that are distributed and conclusion letters that are not;

ii. The syllogism is valid if and only if every capital letter is starred exactly once and there is exactly one star on the right-hand side." (Gensler 2010, 10) 
Syllogism A passes the star test and I will henceforth take it as unquestionably valid. (For proof of the star test, see Gensler 1973.)

The-Truth-in-Soundness: Soundness is validity plus true premises (yielding, therefore, a true conclusion). But what is truth? Following Kwasi Wiredu's analysis of the Akan conception of truth, I accept that truth is opinion; that any item of information that is labeled "true" is always someone's truth-that is, an item of information must have been identified by, discovered by, and defended by some person at a specific point in time before "truth" can be ascribed to it. This has some implications:

i. Truth is not objectivist. That is, truth is not timeless or eternal because any item of information that is defended as true by someone may be shown to be a falsehood by someone;

ii. Truth requires cognitive agency; it is an activity that requires language, reason, perception, and inference.

Culture: Culture is the manifestation of human intellectual achievements collectively and universally as a "grouping." Culture has three dimensions or layers:

i. Communal culture (CC) is at the level of group psychology, which I here define as the shared set of beliefs, doings, and practices that makes up the communal bank of a group's achievements. Communal culture is observable. For example, the use of the English language and the Spanish language in the United States are manifestations at the level of communal groupings. Other examples would include modes of dress, types of food, etc.

ii. Internal culture (IC) is individual psychology, which I here define as the mental characteristics or elements of grouping psychology as imbibed, absorbed or assimilated in a person. E.g., Kọlá's use of the English language in writing this article; or John's conception of the professional attire as a business suit in dark colors and of a conservative cut; or Mary's claim that $2+2 \neq 10$ because she only counts in base 10 (and not in base 4 where $2+2=10$ ); are all elements of "grouping psychology" as imbibed by Kọ́lá, John, and Mary respectively.

iii. Nomological culture (NC) is sociobiological psychology, which I here define as habits or customs of the human mind that have resulted from evolutionary groupings that now function as prerequisites for human cognition and inference. E.g., the capacity to form generalizations and their usages as inferential warrants in thinking (Abímbọ́lá 2013b and 2005); or the indispensability of a conception of space/time to human cognition; or the innate capacity of humans to communicate with spoken languages. 
Therefore: Any product of thought designated as "philosophy" is cultural philosophy if and only if it is impossible to convey that thought without reliance on collective manifestations of human groupings of the CC, IC, and NC types.

I should add that communal, internal, and nomological cultures are distinguishable but not distinct. They come in a package deal as the three sides (obverse, reverse, and edge) of the same coin.

Abductive Generalization: The principle of abductive generalization can be stated as follows:

Suppose that something is true in the first case, and assume that if it is true in any $\mathrm{n}$ case, then it is also true for the $\mathrm{n}+1$ case. Then that something is true in all cases.

This has two properties:

Base case: Show that something is true for the first case. I.e.:

$P(1)$ is true, and

Abduction step: Assume that if any one $n$ is true, then it is also true for $n+1$. I.e.:

$P(n) \rightarrow P(n+1)$ for all cases of $n$.

This method of proof can be stated formerly as follows:

$[P(1) \wedge \forall n(P(n) \rightarrow P(n+1))] \rightarrow \forall n P(n)$

What I have called abductive generalization is more commonly known as mathematical induction; but since it operates more like abduction (or inference to the best explanation) than induction, I refer to it as abductive generalization.

Abductive generalization can be defined as the converse of inductive generalization. $Q \rightarrow P$ is the converse of $P \rightarrow Q$; All $P$ is $S$ is the converse of All $S$ is $P$. In inductive generalizations, we find a generalization such that all examples can be derived from it; whereas in abductive generalizations, we find a generalization that can be deduced from all examples.

It could be objected that the specificity of my definitions is unnatural; that the meanings of these terms ought to be established by examining their semantic expressions in ordinary language. But that would be absurd. Philosophy, as I shall argue, cannot run solely on monadic semantic expressions that are devoid of a meaning-use duality. Understanding the statement "she took out her key and opened the door" implies that she opened the door with the key she took out; and that is an understanding that does not just inhere in the meanings of the words; but also in their usage; and therefore also in cultures 
CC, IC, and NC. Simply put, understanding is not just about the semantics of sentences; it also includes the pragmatic process of meaningful usage that Grice calls "conversational implicature" (Grice 1989); a process within which the philosopher and her cultures cooperate in concert to produce second-order thought.

\section{History and the Nature of African Philosophy}

At least three ways of doing history can be identified: history I, history II, and rational reconstructions. History I is about the constellations of facts. It is about recording factual events that have occurred in time. The "facts" are often conceived of as "observable" and "real" things that are (or were) in existence, and have (or had) independent positivity in some sense. History II is concerned with the development or evolution of ideas and their roles in human understanding. Just as we can have chronological accounts of observable facts in history I, we can also have chronological accounts of history II concepts. I could give a chronological account of schools of thought such as: ethnophilosophy, sagacity, Afrocentricity, the phenomenological approach to African philosophy, and the socialist/Marxist approach to African philosophy. Moreover, a chronological account of these ideas, concepts, or schools of thought could also be interpretative. (See, for example, Oruka 1981.) For instance, in the chronological ordering of ideas, Africentrics could reflect on the similarities between the Egyptian ethical principles of Maat, the Yorùbá concept of iwàpẹlé, and Aristotelian virtue ethics; and they could assert the international dominance of Egyptian culture by maintaining that iwàpẹlé and Aristotelian ethics originated from Egyptian culture.

Rational reconstruction is historiography. In this context, it is the study of the history and methods for doing the history of African philosophy. It involves a dialectical interaction between histories I and II, an epistemological thesis about the sources of historical knowledge, the methods of historical knowledge, and an axiology. Rational reconstruction in this context is a meta-epistemological stance on the nature of African philosophy. In doing rational reconstructions, the historian generates her own methods (or relies on a specific method) for the study of historical material as well the specific body of works to focus on.

How then should we write the history of African philosophy? On the basis of history I, history II, or rational reconstructions? As Collingwood rightly pointed out, "the historian's picture of the past is [...] in every detail an imaginary picture, and its necessity at every point is the necessity of the a priori" (Collingwood 1978, 244). One way of interpreting Collingwood's claim is that it is the historian's engagement with the past that makes or creates the events 
as "historical facts." Every knowledge claim about the past is of necessity constrained by various factors: the fact that the events are no longer there for us to observe, the fact that we now have only a selective section of the sequence of events that transpired, and above all the fact that interpretation plays an indispensable role in everything the historian records as historical fact.

There would be no historical fact without the historian. And consequently, it would seem to be the case that we can never genuinely have a history I account of the history of African philosophy, for each "constellation of facts" about the past requires the grouping or clustering of things that are related in a particular way, and this must of necessity go beyond the "observable," the "real," and beyond constituents of human existence that have (or had) independent positivity. Any so-called history I account of African philosophy will ipso facto be a constellation on the basis of a history II construct such as Afrocentricity, sagacity, analytic philosophy, or Marxist philosophy. Any history I account of African philosophy will of necessity be a priori because it will constellate facts on the basis of an imagined picture. We cannot have history I without the constituents of history II, mutatis mutandis, a rational reconstruction.

Consider, for instance, the following claims by Lefkowitz:

I use the term philosophy in the more specialized, modern sense, to mean the study of causes and laws underlying reality or a system of inquiry designed specifically to study those laws and causes. The ancient Egyptians and Babylonians were learned and had what we would now call advanced civilizations; they could have developed an abstract terminology for discovering causes and principles had they chosen to do so. But they did not study and analyze the nature of reality in abstract, nontheological language. This specialized notion of philosophy was invented, so far as anyone knows, by the ancient Greeks. (Lefkowitz 1996, 188-89; my italics.)

First, based on the accounts of many other accepted super-rational reconstructions (i.e., other accounts of what philosophy is), Lefkowitz's account of philosophy as "the study of causes and laws underlying reality" jettisons from philosophy sub-fields of knowledge such as ethics, political philosophy, and aesthetics, which are not in the business of doing metaphysics and ontology. Hence her definition of philosophy is too restrictive.

Moreover, even if we accept Lefkowitz's own criteria of philosophy as "the study of causes and laws underlying reality," or "a system [. . .] to study [. . . ] laws and causes," or analysis of "the nature of reality in abstract," there are numerous examples of African thought systems that meet these specific criteria. Theophile Obenga makes this point poignantly as follows: 
Egyptian thinking was graphic and abstract at the same time. Pictures were used as symbols of thought. [.. .] The Egyptians did develop a kind of semiology by studying the relationship between signs and pictures, using material objects to represent something invisible or abstract. This is not to say that the Egyptian philosophers thought in graphic and concrete terms. They made use of graphic and concrete forms to think abstractions. This may seem quaint for the modern mind, because of the alphabetical system of writing. In fact, semiotic structures in hieroglyphic signs were a fine equipment for precise abstract thinking. $(2004,34)$

Lefkowitz's account is based on a rational reconstruction that is the product of a self-created constellation of historical patterns. But so too is Obenga's! The judgment that Obenga's rational reconstructions are better than Lefkowitz's requires: (i) assessing them on Thomas Kuhn's fuzzy criteria of simplicity, accuracy, consistency, and fruitfulness (Kuhn 1977; Kuhn 1962); and (ii) searching for a super-rational reconstruction on the basis of which both of these options can be judged.

I submit that Afrocentricity, sagacity, Bantu philosophy, the Lefkowitz account and its Obenga critique, or any other rational reconstruction, will never succeed in capturing the essential nature of African philosophy because each rational reconstruction in part creates its own scheme of fact, methods, and values. Rather, in varying degrees of success or failure, they rationally reconstruct the different and changing patterns of the intellectual circumstances and possibilities that originate from Africa. We are still none the wiser on the essential nature of African philosophy.

In summary:

Doing history I requires a prior knowledge of elements and concepts of history II;

The elements and concepts of history II are of necessity biased because they contain within themselves their own yardstick for what should count as fact, the methods for conducting historical research, and their own axiology of values; and,

As such, a mere constellation of history IIs (Afrocentricism, sagacity, analytic philosophy, etc.) will never yield a full picture of what African philosophy is. We need to engage with the essential nature of philosophy in itself and African philosophy's share of it.

\section{Premise 1: All Philosophy is Cultural Philosophy}

I want to prove that the first premise of Syllogism A is true. Let us label this premise as: abductive generalization I (AGI). 
AGI: All philosophy is cultural philosophy.

It is impossible to prove this statement by induction for there will be an inference gap in the reasoning since the premises of an inductive argument will never entail its conclusion. We also cannot prove this statement by deduction because deductive reasoning is non-ampliative, and unless AGI is already covertly (or explicitly) contained in the premises of that deductive argument, the truth of those premises will never guarantee the truth of AGI.

Hence, I will advance a proof by abductive generalization. AGI asserts that the property "cultural philosophy" holds for all philosophical systems 1, 2, 3, 4, ad infinitum. The proof will proceed as follows:

Base case: $P(1)$ is true (where $P(1)$ is the following):

Suppose that "philosophy is cultural philosophy" is true with respect to thoughts expressed in the English language (i.e., the first case); and, Abduction step: $P(n) \rightarrow P(n+1)$ for all cases of $n$

Assume that if "philosophy is cultural philosophy" is true in philosophy expressed in any unspecified language (i.e., the $n$th case), then it is also true for any language we choose after that $n$th case (i.e., the $n+1$ th case). Then that something is true in all cases.

Such a proof would amount to establishing:

$[P(1) \wedge \forall n(P(n) \rightarrow P(n+1))] \rightarrow \forall n P(n)$

which is a proof that shows that:

if it is possible to show that philosophical thoughts expressed in the English language are cultural philosophy, and that for any unspecified language $\mathrm{n}$, if you can show that philosophy expressed in that language is cultural philosophy, then you can also show that the $\mathrm{n}+1$ th philosophy you reach will also be cultural philosophy.

Is $P(1)$, the base case, true? Is it the case that philosophizing in the English language will always be about the "collective" and "universal" manifestations of human intellectual achievements of the "grouping" of people called the English - that nation and ethnic group native to England? (Note, of course, that the base case need not be the English language. The beauty of abductive generalization here is that any natural language can be taken to be the base case. Note further that the cultural identity of the base need not be the English of England. If the language chosen were "American English," then the ethnic/ cultural group in question would be the English-speaking Americans of the United States.) 
Talking about the world in any language relies upon "sortals." Sortals provide the criteria of individuation ("how many?") and the principles of identity ("is it the same?") in a language. If I ask the question "how many?" there is no intelligible way to answer that question until I specify how many of what should be counted. Hence, the answer to the question "how many?" can only be answered if a language has principles and criteria for the individuation of the sorts of "countable things" in that natural language. Criteria of individuation and the principles of identity are embedded into each language as sortals. Differently put, sortals code individuation and identity in natural languages.

In the English language, the criteria (and principles) of individuation and identity are spatiotemporal in the sense that particulars have identities because they are individuated sections of matter that are located in particular spaces, and that exist across time with designated identities. Sortals, in the English language, must have spatiotemporal location; they have to be space-filling and enduring over time.

It is "natural," but erroneous, to assume that spatiotemporality is the only correct way of individuation and identity. This method of doing sortals seems natural only to speakers of European languages such as English. Moreover, it is certainly possible for speakers of non-European languages to falsely assume spatiotemporality as the only valid means of doing sortals because of the hegemony of European languages in philosophy, linguistics, psychology, and other such disciplines.

Contrast Yorubá, for example, with the English language. If I point at three different items and ask of each one in English "what is this," the answers "It is water," or "It is money," or "It is a head" rely on criteria of individuation and identity that are spatiotemporal. A somewhat equivalent question in the Yoru bá language would be the question: “kí niyi ?" Helen Verran $(2001,2007)$ provides novel analysis of questions of this type. Verran's analysis demonstrates that if I point at "water," "money," or "a head" and ask a monolingual or a competent bilingual speaker of the Yoru bá language " $k i$ niyi'?", the answers to these questions in Yorubá would be: "Omi ni ó jẹ," "owo ni ó jẹ," and "orí ni ó jẹ." It would however, be misleading to translate:
a. "Omi ni ó jẹ" as "It is water"
b. "Owó ni ó jẹ" as "It is money," and
c. "Orí ni ó jẹ" as "It is a head."

This is because a competent Yorubá speaker does not primarily identify and individuate on the basis of spatiotemporality. Rather, they identify and individuate on the sorts, categories or types of features that exist in common 
in a conceptualized, non-spatiotemporal metaphysical unity. Hence, the better translations would be:
d. "Omi ni ó jẹ" as "watermatter manifests"
e. "Owó ni ó jẹ" as "moneymatter manifests," and
f. "Orí ni ó jẹ" as "headmatter manifests."

These may sound totally unintelligible to an English speaker. In her analysis, Helen Verran focused on the answers to these questions. I will approach them from the point of the question "kí niyi i?" ("what is this?") itself.

First, we need to be clear on two syntactical and semantic methods of the Yorủbá language.

a. In its arrangement of words and phrases to create well-formed sentences, Yoruba language adopts the method of assimilation and elision.

b. In its logic of meanings, the Yoruba' language adopts the method of layering.

Here is an example of these two methods at work. Consider for instance the name Kọ́lápọ̀ Abímbọ́lá. The sentence kí olá pọ, which means: "may honor be plentiful," now becomes the name "Kọ́lápọ̣." The sentence a bí mi bá olá, which means: "in a setting where we were born with lots of honor" now becomes the name "Abímbọla." (Note that it is "we" were born, not "you" were born. This is because Abímbọ la in this context refers to the extended Abímbọ́lá family, and not just the individual named Kọ́lápọ Abímbọ́lá. Hence, the $m i$ in a bi mi bá ọlá refers to an extended family of about 2,500 people, and not just to the individual named Kọ́lápọ.)

The first layer of meaning for the name Kọ́lápọ Abímbọ́la would be the following: "here is another contribution to honor in a lineage where honor is already plentiful." This first layer of meaning is, however, too superficial; and, in fact, the English translation above is woefully misleading. To be sure, the word ola' in my names is somewhat equivalent to the word "honor" in English; but in actuality olá in Yorubá is an appearance (a particular or an instance) of a manifestation (or a universal) whose primordial real form is the metaphysical entity/power/force/logic that the Yoruba' call Eșù. This supernatural entity/power/force functions as the neutral "universal law" that cosmically wields the balance of good and evil. In Yoruba' metaphysics and logic, there is good, there is evil, and there is a third middle of perfect "neutrality" in-between them. What we have is a Yoruba' metaphysics and a corresponding intuitionistic/fuzzy logic that violates classical logic's law of excluded middle. 
In Yorủbá logic, the statement "a proposition is true or its negation is true" is not necessarily a true statement. For, there is a third truth-value encoded into the language.

The true meanings of my names can only be deciphered by paying attention to the fact that Eșu, that third truth-status (neutral?) metaphysical entity/ power/force/logic is always present with Ifá priests and priestesses (watching, accompanying, supporting, testing, judging, and rewarding them) because they are the physicians, philosophers, counselors, doctors and historians of Yorubá societies. In short, my name is as much an affirmation as a warning: it affirms that I am from a lineage of Ifá diviners and that if I follow the ethical virtues of iwapẹlé (as those before me in this lineage did), my path in life will be filled with ire (i.e., blessing); but if I deviate from a path of i wàpẹ lé and good conduct, Eșù is always there watching everything I do, and will surely act as required by cosmic law.

Assimilations, elisions, and layered meanings of the type illustrated with my names are all embedded in the question: "kí niyi i $i$," which is in fact the condensed version of the question: "kin ni ti irú oni eyi ?" The word-for-word equivalents for this longer question are:

\begin{tabular}{|l|l|l|l|l|l|}
\hline Kín & $n i$ & $t i$ & irú & oní & $\grave{e y i ́ ? ~}$ \\
\hline What & manifesting or appearing & is & type & $\begin{array}{l}\text { belongs to } \\
\text { (or, "is } \\
\text { crafting") }\end{array}$ & this? \\
\hline
\end{tabular}

With a series of Yorủbá assimilations, elisions and layering of meanings:

kin ni ti irú oni è yí becomes shortened to

kin ni ti irú èyí, which becomes shortened to

kin ni ti eléyi í, which becomes shortened to

kin ni èléyi i $i$, which becomes shortened to

kín léyií (or its equivalent shortened versions of kin niyií or kí niyií).

(Note that any version of these alternatives can be validly used in Yorubá conversation.)

To convey the exact metaphysical and epistemological ideas intended by a competent speaker of Yoruba into English, the honest translation of the question ki niy i ' ? should be: To what type of manifestation does this type of appearing belong? Or better still: To what type of universal does this type of particular belong?

To be clear: the manner in which individuation and identification work in the Yoruba' language is radically different from that of the English language. 
When a native speaker of Yoruba' sees the object that an English speaker would regard as a spatiotemporal sortal, the Yorubá speaker sees more; the Yorubá speaker in fact sees the appearing of a manifestation!

This explains why, in conversing with a native Yoruba speaker, the question: "kí niyí í" with respect to "water," "money," and "orí" elicits the following responses:
a. "Omi ni ó jẹ" (watermatter manifests);
b. "Owó ni ó jẹ" (moneymatter manifests); and
c. "Orí ni ó jẹ" (headmatter manifests).

Translation from Yorubá into English and vice versa is fun! You see and understand things differently by code-switching in and out of the two languages. But at the same time, it is perilous! From Kindergarten through the doctoral level, I was schooled in two radically different educational systems: the formal Western educational system and the apprenticeship-based Yoru bá indigenous knowledge system in which I was studying to be an Ifá diviner. The Ifá Corpus has 256 books, each of which has 800 poems, making a total of 204,800 poems. The shortest poem is four lines, and there are some that run into 30 pages when written down.

Even though we are dealing with two languages, there are in fact five main classes of linguistic competence to engage with:

Native-level Yorubá speakers who are monolingual;

Native-level speakers of English who are monolingual;

Native-level Yorubá speakers who have native-level fluency in the English language;

Competent-level Yoru bá speakers who also have competent-level status in the English language; and

Native-level Yorubá speakers who had rudimentary-level understanding of the English language.

(Note: there are other classes of linguistic competency. For instance: competent-level speakers of Yoru bá who have native-level status in English; Ifá diviners from Cuba who speak Cuban Yorubá and Spanish; or Candomblé practitioners from Brazil who speak Brazilian Yoru bá and Portuguese.)

Imagine that I am functioning as a translator for two monolinguals-a native-level Yorubá speaker and a native-level English speaker. If the Yoru'bá speaker were to ask the question: kí ni yií? (given that I understand his worldviews and the presuppositions of his question) the honest translation I should render to the English speaker should be: "to what type of manifestation does this appearing belong?" The English speaker would be bewildered at my 
translation. If the English speaker were to ask what is this? My honest translation (given her worldview and the presuppositions of her question) should be a Yoru ba' statement approximating something like "what is the identity of the spatiotemporal matter located here?" No doubt the Yorubá speaker would think that the English speaker (or the translator) has lost some marbles!

The implication of the foregoing is clear: doing philosophy in the English language will yield a completely different set of rules, principles and standards from doing philosophy in the Yoru bá language because these languages individuate and identify in radically different ways. The law of identity which states that "each thing is the same with itself and different from another" only appears to be intuitively valid in the English language because spatiotemporality is coded into English-a language that is the collective cultural manifestation of the intellectual achievements of the English people as exhibited in communal, individual, and nomological psychology. The primary logic of Yoruba language is not classical; it is intuitionistic or sortal at base, with a secondary or supplementary layer of classical logic.

Effective communication in the places where I grew up (the campus of Ọbáfẹmi Awólọ́wọ University, the city of Ilé-Ifẹe, and the city of Ọyọ́) required complex but seamless code-switching in engaging with peoples with the five different Yoruba/English language-competency mixes.

Every truly bilingual speaker of the Yoru bá and English languages learns to code-switch seamlessly. The codes switched between depend on the language competency level of those one is conversing with. Many concepts, principles, actions, processes, rules, and methods simply do not make sense if one thinks in Yoru bá on the basis of the spatiotemporal classical logic that is encoded into the English language. Many concepts, principles, actions, processes, rules and methods simply do not make sense if one thinks in English on the basis of the intuitionistic, fuzzy or sortal logic that are encoded into the Yoru bá language.

I am now in a position to assert that the Base case $\mathrm{P}(1)$ is true with respect to the English language. The forgoing discussion on sortals and the spatiotemporal criteria of individuation and identity in the English language demonstrably shows that philosophizing in English requires reliance on the principles of classical logic that are culturally codified in the language of the English people.

I am now also in a position to assert that the abduction step $\mathrm{P}(\mathrm{n}) \rightarrow \mathrm{P}(\mathrm{n}+1)$ for all cases of $n$ is proven. In proving the base case with respect to the English language, I have shown that the sortals of individuation and identity are essential and cultural. But if we take any other language $n$, sortals will also be required in that language and they will also be cultural. (And this I have also 
shown with another $n$ that is not the English language; namely, the Yoruba' language.) Hence:

$$
[P(1) \wedge \forall n(P(n) \rightarrow P(n+1))] \rightarrow \forall n P(n)
$$

Less formally, this proof states that:

Suppose that the claim that "philosophy has the property of cultural philosophy" holds for the first $\mathrm{n}$ cases (in this article the first $\mathrm{n}$ th case has been shown to be the English language); then the property of philosophy as cultural philosophy holds in the $\mathrm{n}+1$ th case (i.e., any other language we choose after establishing that this property holds for the English language as the first $\mathrm{n}$ th case). Then the property of philosophy as cultural philosophy holds in all cases.

The only condition under which this abductive generalization would fail is that in which we philosophize without communicating in a natural human language.

\section{Premise 2: Yorubá Thought is Philosophy}

Clearly, this premise is not a universal generalization! It does not claim that all Yoruba thought ipso facto classifies as philosophy; rather, it claims that at least some does. I will illustrate this claim with examples.

\section{Classical Yorùbá Thought as Philosophy}

In the preface to Yorubá Culture: A Philosophical Account, I make the following claims:

This is a book about Yorùbá thought and practices. It expounds a view about the nature, roles and functions of Yorùbá beliefs in contemporary societies. My position is that philosophical ideas implicit in the Òrìsà religion form the basis of Yorùbá culture in West Africa, the Americas, and other parts of the world. The book is, therefore, not a catalogue of various cultural practices of Yorùbá peoples around the world. It is not an exposition of tastes in art, dance, etiquette, and other mores that are adopted by this particular social group. It is simply a theoretical account of the philosophical ideas that underlie the world-view of traditional Yorùbá societies." (Abímbọ́lá, K. 2006, xv.)

Works of this type are "classical" because they seek to identify the underlying concepts, categories, and viewpoints that are embedded within, and have 
persisted in the exegesis of, Yoruba thought and culture. Other examples of works of the classical type, would include Gbadegesin (1984), Makinde (1983), and Sodipo (1973).

\section{Modern Yorubá Thought as Philosophy}

In his foreword to the American edition of Hallen and Sodipo's Knowledge, Belief, and Witchcraft: Analytic Experiments in African Philosophy, W. V. O Quine writes:

This book is philosophical and linguistic, serving both interests. On the philosophical side it embodies the spirit of the philosophy of ordinary language, which flourished in England in the middle decades of this century; but the language concerned, Yoruba, is far from ordinary from an English point of view. The central epistemological themes of truth, belief, knowledge and evidence are explored through analytic study of the usage and connotation of the key terms: not these four words to be sure, but the accepted dictionary counterparts in Yoruba. [. . .] Hints of an alien philosophical orientation emerge [...] This could enrich one's own attitude with a new perspective [. . .]. (Hallen and Sodipo 1997, xiii)

Works of this type I describe as "modern" because their primary focus is on intercultural analysis of the compare-and-contrast type. They are intercommunicative dialogues between Yorubá and other cultures. Other works within this genre would include Gbadegesin (1991, 1987), Taiwo (2004), and Verran (2001).

\section{Non-Philosophical Sources of Yorủbá Thought as Philosophy}

A wealth of writings from the fields of religion, literature, sociology, anthropology, etc. have also produced Yorubá philosophical materials. In fact, in the 1970s and early 1980s when many academic philosophers were still bogged down with the question of whether there is an African philosophy (perhaps because they were thinking about African thought in European languages), scholars in these other fields just went on with the business of doing African philosophy in general, and Yorubá philosophy in particular. Works within this genre include W. Abímbọ́lá (1977, 1973, 1968), Abiọ́dún (2014), Oyewumi (1997), and Soyinka (1976).

\section{Conclusion: Yoruba thought is Cultural Philosophy}

Given the truth of premises 1 and 2, we can conclude that Yorubá thought is cultural philosophy. 


\section{Implications of the Syllogism for African Philosophy}

Ian Hacking rightly observed that "language matters to philosophy in the way it matters to all extended thought: we express and communicate our ideas in language" (Hacking 1975, 4). Hacking continued: "We shall avoid confusion if only we attend closely enough to distinctions actually present in common speech" (Hacking 1975, 6).

Prior to the hegemony of philosophy in academia, the primary source of philosophy in African societies were those specialists (so-called "illiterates" and "uneducated") of second-order thinking who thought, critiqued, and conversed in their indigenous African languages (see W. Abímbọ́lá [1975], Oruka [1983], Hallen and Sodipo [1997], and Griaule [1965] for analysis and illustrations of non-professional, non-academic-based African philosophy).

Philosophy is now burgeoning across Africa as an academic discipline. Yet, notwithstanding the contemporary growth and success of philosophy on the African continent, not one single academic program across the continent is conducted in an indigenous language. The languages of professional academic philosophical training, philosophical education, and philosophical writing in Africa are all European and Arabic.

To be sure, many African scholars have very poignantly argued that the language of education does matter. June 2015 marks 35 years since the Ghanaian philosopher Kwasi Wiredu called for the decolonization of African philosophy from "the conceptual frameworks embedded in the foreign philosophical traditions that have had an impact on African life and thought" (Wiredu 1996, 136). Scholars of the so-called "illiterate" type (listed above) have also written extensively on why the language of education, philosophizing, politics, art, and culture matter in Africa. Notable amongst these writings are Abiodun (2014), Oyewumi (1997), Wiredu (1996), and Wa Thiong'o (1994).

Many concepts, such as truth, reality, being, matter, existence, personhood, democracy, citizenship, soul, minds, etc., are still being conceptualized in colonized European languages in the doing of philosophy in Africa. Indeed, there are some African universities where indigenous languages are being taught in European languages!

To be sure, comparative analysis, second-order presentations of African thought systems in non-African languages, and the learning of more than one language are of immense value. However, these should not be at the demise of the logics, metaphysics and epistemologies that are embedded within the indigenous languages that are used routinely on a daily basis across the African continent.

Wiredu's call for the conceptual decolonization of African philosophy has not yet been heeded, and as such professional academic philosophy in Africa 
has found itself in a precarious and paradoxical position: the development of philosophy in Africa is leading to the demise of African philosophy!

\section{Bibliography}

Abímbọ́lá, Kọ́lá. "Culture and the Principles of Biomedical Ethics." Journal of Commercial Biotechnology 19, no. 3 (2013): 31-39.

- - " "God and Evil." Philosophy Now 8 (1994): 23-25.

- - - "Medicine and Culture: Transcultural Needs in Modern Western Societies." The AvMA Medical and Law Journal 13, no.3 (2007):112-116.

- - " "Questions and Answers: The Logic of Preliminary Fact Investigation." The Journal of Law and Society 29, no. 4 (2002): 533-559.

- - - "Reason and Proof in Forensic Evidence." Journal of Forensic Research S11, no 006 (2013b): 1-8.

- - . "Spirituality and Applied Ethics: An African Perspective." West Africa Review 3, no. 1 (2001): 1-29.

- - Yorùbá Culture: A Philosophical Account. Birmingham: Iroko Academic Publishers, 2006.

-_- "Yoruba Diaspora." In Encyclopedia of Diasporas. Immigrant and Refugee Cultures Around the World, edited by Melvin Ember, Carol R. Ember, and Ian Skoggard, I, 317-326. New York: Kluwer Academic Publishers, 2004.

Abímbọ́lá, Wándé. "The Bag of Wisdom: Osun and the Origins of Ifa Divination." In Osun Across the Waters, edited by John Murphy and M. Sanford, 141-150. Bloomington: Indiana University Press, 2001.

- - - Ifa: An Exposition of Ifa Literary Corpus. Ibadan: Oxford University Press, 1977.

- - - "Ifa as a Body of Knowledge and as an Academic Discipline." Lagos Notes and Records 2, no. 2 (1968): 30-40.

- - - "The Notion of Sacrifice in Yoruba Religion." In Restoring the Kingdom, edited by Dean Williams Ferm, 175-181. New York: Paragon House, 1984.

- - - "The Yoruba Concept of Human Personality." In La Notion de Personne en Afrique Noir, C.N.R.S., 41-62. Paris: UNESCO, 1973.

_-_. Yoruba Oral Tradition. Ibadan: University Press Limited, 1975.

Abiodun, Rowland. Yoruba Art and Language: Seeking the African in African Art. Cambridge: Cambridge University Press, 2014.

Abraham, W. E. The Mind of Africa. Chicago: The University of Chicago Press, 1962.

Collingwood, R. G. The Idea of History. Oxford: Oxford University Press, 1978. 
Gbadegesin, Segun. African Philosophy: Traditional Yoruba Philosophy and Contemporary African Realities. New York: Peter Lang, 1991.

- - - "Destiny, Personality and the Ultimate Reality of Human Experience: A Yoruba Perspective." Ultimate Reality and Meaning 10, no. 1 (1984): $173-188$.

- - . "God, Destiny and Social injustice: A Critique of Yoruba Ifa Belief." In The Search for Faith and Justice in the Twentieth Century, edited by Gene James, 52-68. New York: Paragon, 1987.

Gensler, Harry. Introduction to Logic. New York: Routledge, 2010.

Gensler, Harry J. "A Simplified Decision Procedure for Categorical Syllogisms." Notre Dame Journal of Formal Logic. 14, no. 4 (1973): 457-466.

Griaule, Mercel. Conversations with Ogotemmeli: An Introduction to Dogon Religious Ideas. London: Oxford University Press, 1965.

Grice, Herbert Paul. Studies in the Way of Words. Cambridge: Harvard University Press, 1989.

Haack, Susan. Deviant Logic, Fuzzy Logic: Beyond Formalism. Chicago: The University of Chicago Press, 1974.

Hacking, Ian. Why Does Language Matter to Philosophy? Cambridge: Cambridge University Press, 1975.

Hallen, Barry. A Short History of African Philosophy. Bloomington: Indiana University Press, 2009.

Hallen, Barry, and J. Olubi Sodipo. Knowledge, Belief, and Witchcraft: Analytic Experiments in African Philosophy. Stanford: Stanford University Press, 1997.

Kuhn, Thomas. The Essential Tension: Selected Studies in Scientific Tradition and Change. Chicago: University of Chicago Press, 1977.

- - - The Structure of Scientific Revolutions. Chicago: University of Chicago Press, 1962.

Kuper, Adam. The Invention of Primitive Society. London: Routledge, 1988.

Laudan, Larry. Science and Values: The Aims of Science and Their Role in Scientific Debate. Berkeley: University of California Press, 1984.

Lefkowitz, Mary. Not Out of Africa: How Afrocentrism Became an Excuse to Teach Myth as History. New York: Basic Books, 1996.

Makinde, Moses A. "Immortality of the Soul and the Yoruba Theory of Seven Heavens (Orun Meje)." Journal of Cultures and Ideas 1, no.1 (1983): 31-59.

Mudimbe, V. Y. The Idea of Africa. Bloomington: Indiana University Press, 1994.

Obenga, Theophile. "Egypt: Ancient History of African Philosophy." In A Companion to African Philosophy, edited by Kwasi Wiredu, 31-49. Malden: Blackwell, 2004. 
Oruka, H. Odera. "Four Trends in Current African Philosophy." In Philosophy in the Present Situation in Africa, edited by Alwin Diemer, 71-83. Wiesbaden: Franz Steiner Verlag, 1981.

- - . "Sagacity in African Philosophy." International Philosophical Quarterly 23, no. 4 (1983): 383-393.

Oyěwumi, Oyèrónkẹ. The Invention of Women: Making an African Sense of Western Gender Studies. Minneapolis: University of Minnesota Press, 1997.

Sodipo, J. O. "Notes on the Concept of Cause and Chance in Yoruba Traditional Thought." Second Order 2, no. 2 (1973): 12-20.

Soyinka, Wole. Myth, Literature and the African World. Cambridge: Cambridge University Press, 1976.

Taiwo, Olufemi. "Ifa: An Account of a Divination System and Some Concluding Epistemological Questions." In A Companion to African Philosophy, edited by Kwasi Wiredu, 304-312. Malden: Blackwell, 2004.

Tempels, P., E. Possoz, and M. Read. Bantu Philosophy. Paris: Présence Africaine, 1959.

Verran, Helen. Science and an African Logic. Chicago: University of Chicago Press, 2001.

Wa Thiong'o, Ngũgĩ. Decolonising the Mind: The Politics of Language in African Literature. Nairobi: East African Publishers, 1994.

Wilson, Amos N. The Falsification of Afrikan Consciousness: Eurocentric History, Psychiatry and the Politics of White Supremacy. Brooklyn: Afrikan World Infosystems, 1993.

Wiredu, Kwasi. Cultural Universals and Particulars: An African Perspective. Bloomington: Indiana University Press, 1996.

- - - Philosophy and an African Culture. Cambridge: Cambridge University Press, 1980. 